\title{
Factors associated with child sexual abuse confirmation at forensic examinations
}

\author{
Fatores associados à confirmação por exame médico legal \\ de abuso sexual infantil
}

Welington dos Santos Silva ${ }^{1}$

Filipe Moraes Ribeiro ${ }^{2}$

Gabriel Kamei Guimarães ${ }^{2}$

Matheus de Sá dos Santos ${ }^{2}$

Victor Porfírio dos Santos Almeida ${ }^{2}$

Ubirajara de Oliveira Barroso-Junior ${ }^{1}$

${ }^{1}$ Escola Bahiana de Medicina e Saúde Pública. Av. D. João VI 275, Brotas. 40290-000 Salvador BA Brasil. welssilva@yahoo.com.br ${ }^{2}$ Faculdade de Medicina da Bahia, Universidade Federal da Bahia. Salvador BA Brasil.

\begin{abstract}
The aim of this study is identify potential factors associated with child sexual abuse confirmation at forensic examinations. The forensic files of children under 12 years of age reporting sexual abuse at the Nina Rodrigues Institute of Forensic Medicine in Salvador, Bahia, Brazil between January 2008 and December 2009 were reviewed. A multivariate analysis was conducted to identify factors associated with finding evidence of sexual abuse in forensic examinations. The proportion of cases confirmed by the forensic physician based on material evidence was $10.4 \%$. Adjusted analysis showed that the variables place of birth, type of abuse reported, family relationship between the child and the perpetrator, and the interval between the reported abuse and the forensic examination were not independently associated with finding forensic evidence of sexual abuse. A report of penetration was associated with a five-fold greater likelihood of confirmation, while the victim being 10-11 years of age was associated with a two-fold of abuse confirmation than younger children. These findings should be taken into consideration when drawing up guidelines for the multidisciplinary evaluation of children suspected of being victims of sexual abuse and in deciding whether to refer the child for forensic examination.
\end{abstract}

Key words Child sexual abuse, Paedophilia, Rape, Sexual violence
Resumo O Objetivo deste estudo é identificar potenciais fatores associados à confirmação de abuso sexual infantil no exame médico legal. Foram revisados os laudos de sexologia forense realizados em crianças menores que 12 anos que relataram abuso sexual no Instituto Médico Legal de Salvador, Brasil, no período de janeiro de 2008 a dezembro de 2009. Análise multivariada foi utilizada para identificar fatores relacionados à confirmação de abuso sexual pelo exame médico forense. A proporção de casos confirmados pelo médico legista com base em evidencia material foi de 10,4\%. A análise ajustada demostrou que as variáveis naturalidade, tipo do relato de abuso, parentesco com $\mathrm{o}$ agressor, $e$ intervalo entre o abuso relatado e a perícia não estão independentemente relacionadas à confirmação de abuso sexual em exame de corpo de delito. A presença de relato de penetração estava associada a uma chance cinco vezes maior de confirmação, e a faixa etária de 10 a 11 anos apresentou uma chance duas vezes maior de ter casos confirmados do que crianças menores. Estes dados devem ser levados em conta no planejamento de diretrizes para a avaliação multidisciplinar de crianças com suspeita de serem vítimas de abusos sexual e na decisão de encaminhamento para exame de corpo de delito.

Palavras-chave Maus tratos sexuais infantis, Estupro, Pedofilia, Violência sexual 


\section{Introduction}

Child sexual abuse is the involvement of a child in sexual activity that he/she is unable to fully comprehend, is not yet prepared for in terms of development, and is unable to consent to. Child sexual abuse also refers to acts that violate the laws or taboos established by society'. It differs from 'sexual games' in which children look at or touch each other's anus or genital areas in that these games do not involve coercion and the players are likely to be of the same age and developmental status ${ }^{2}$. Sexual abuse also includes activities that do not involve contact, such as exhibitionism, voyeurism, or pornography ${ }^{1}$.

Meta-analyses conducted with data from various different countries estimate that by 18 years of age, $20 \%$ of girls and $8 \%$ of boys have been victimized $^{3,4}$. Many child victims of sexual abuse never tell anyone about the abuse they have suffered. Those who manage to report it may have to repeat their story at healthcare units, forensic institutes, and police stations, running the risk of being re-victimized by repeating traumatic and distressing facts.

The World Health Organization's guidelines for the care of victims of sexual violence ${ }^{5}$ emphasize that care should focus on the victim's needs and stress the importance of the integration of care; that is, the care provided to the victim and the forensic examination should take place at the same time and at the same location. Brazil has incorporated several of these recommendations into its legislation ${ }^{6-9}$; however, there remains a need to implement recommendations specifically aimed at children. Child sexual abuse differs substantially from sexual violence involving adults and adolescents, since many cases do not involve penetration ${ }^{10}$ and tend to be reported later, making it unlikely that evidence will be found in the victim's body ${ }^{5}$. The window of opportunity for finding traces of the perpetrator in a child is smaller than in the case of adult victims ${ }^{11}$. In addition, the need to collect material for tests designed to detect sexually transmitted infections should be decided case by case; the collection of sperm from the vagina is seldom indicated ${ }^{12}$. Studies conducted in forensic institutes show that child sexual abuse cannot be confirmed in over $90 \%$ of forensic examinations ${ }^{13,14}$; an evaluation focused only on the forensic examination may serve to discredit the child's report.

A better understanding of the factors associated with the forensic confirmation of child sexual abuse may help predict when material proof is more likely to be obtained at the forensic medical examination. Consequently, the regulations for the multidisciplinary evaluation of victims may be improved, reducing the risk of re-victimization associated with unnecessary examination. The objective of the present study was to identify potential factors associated with the confirmation of sexual abuse in the forensic examination of children reporting sexual abuse.

\section{Methods}

\section{Study design}

A cross-sectional, retrospective study was conducted to investigate potential factors associated with sexual abuse confirmation at forensic examinations.

\section{Study site}

The Nina Rodrigues Institute of Forensic Medicine is the referral centre in the greater metropolitan region of Salvador for all forensic examinations, including all cases of sexual violence. Salvador's metropolitan region consists of $13 \mathrm{mu}-$ nicipalities with $3,574,804$ inhabitants according to the 2010 census $^{15}$. The forensic examinations are conducted by the forensic physicians on duty at the institute. The evaluations involve interviews with the alleged victims and/or their family members, a physical examination, and the collection of material for laboratory analysis (beta-hCG for the diagnosis of pregnancy, sperm search, and evaluation of prostatic specific antigen) consistent with the forensic findings. Although the interviews form part of the examination, the conclusions reached by the forensic physicians are based on the material findings obtained.

\section{Sample}

The sample included all consecutive forensic reports issued between January 1, 2008 and December 31, 2009 that met the following eligibility criteria: 1) forensic examination was performed for suspected sexual abuse; 2) the victim was under 12 years of age, and 3) a report of sexual abuse was present in the case history.

\section{Study variables}

The criterion variable was evidence of sexual abuse, coded as [0] when unconfirmed or [1] for 
those cases in which the forensic physician was able to confirm sexual assault at the conclusion of the examination.

The independent variables were as follows:

a) the child's demographic data (sex, age, place of birth and place of residence);

b) the source of the report of abuse: [0] the person accompanying the child reported the abuse to the forensic physician as previously reported to him/her by the child; [1] the child reported the sexual abuse during the interview with the forensic physician; or [2] a family member declared that someone had witnessed the sexual abuse;

c) the type of abuse reported: [0] no report of penetration; or [1] reported digital or penile penetration (anal or genital);

d) interval between the reported abuse and the examination: [0] more than 15 days; [1] up to 24 hours; [2] between 24 and 72 hours; [3] between 3 and 7 days; or [4] between 8 and 15 days;

e) the perpetrator's sex; and

f) family relationship between the perpetrator and the child: [0] no or [1] yes.

In the data analysis, the child's age was coded as [0] for those under 10 years of age or [1] for those between 10 and 11 years of age.

\section{Instruments}

The data collection instrument consisted of a standardized form specifically developed for this study.

\section{Data analysis}

The data analysis included the description of absolute and relative frequencies for the categorical variables. Numerical variables with normal distribution were expressed as means and standard deviations, while variables with non-normal distribution were described as medians and interquartile ranges.

In the inferential analysis, a bivariate analysis was initially performed using the chi-square test to identify potential factors associated with the criterion variable. All variables with a $\mathrm{p}$-value $<$ 0.20 in the bivariate analysis were included in a multivariate model using Poisson regression with a robust error variance ${ }^{16}$. The prevalence ratios, together with their respective 95\% confidence intervals, were calculated as a measure of effect, using the Wald test, to identify the variables associated with sexual abuse confirmation, concomitantly adjusting the effect of each variable for the others included in the model. The variables with a p-value over 0.05 were manually removed one by one and those with a p-value below 0.05 were retained in the final model. After the final model was defined, its goodness-of-fit was verified using Pearson's chi-square test. An omnibus test was used to assess the model's statistical significance. The Statistical Package for the Social Sciences (SPSS), version 17.0 for Windows, was used to construct the database and conduct the analyses $^{17}$.

\section{Ethical aspects}

The internal review board of the Bahia School of Medicine and Public Health approved the study under protocol number 068/10 and the research coordinator of the Nina Rodrigues Institute of Forensic Medicine authorized the data collection.

\section{Results}

Within the study period, 828 forensic reports were selected consistent with the established criteria. In 557 of these cases $(67.3 \%)$, the child reported the abuse personally to the forensic physician during the interview. In 230 cases (27.8\%), the person accompanying the child told the forensic physician that the child had reported sexual abuse prior to the examination. In the remaining 41 cases (4.9\%), someone had witnessed the sexual abuse. The mean age of the children was $7.08 \pm 2.87$ years (mean \pm standard deviation; range: $2-11$ years).

Table 1 describes the population characteristics. Most of the children (78.4\%) were female and had been born and were living in Salvador (71.6\% and $75 \%$, respectively). In almost all the cases, the perpetrator was male. In half of the cases, there was a family relationship between the perpetrator and the child. In most cases, there was no report of penetration. The median time interval between the last episode of reported sexual abuse and the forensic examination was 96 hours (interquartile range: $24-456$ hours). In $10.4 \%$ of the cases, the forensic physician was able to confirm the sexual abuse based on material evidence (95\% CI: 8.4-12.7).

Table 2 shows the distribution of the study variables by the criterion variable (whether $\mathrm{ev}$ idence of sexual abuse was found), with the proportions found then being compared using the chi-square test. Table 3 shows the adjusted prev- 
Table 1. Distribution of the demographic variables, case history data, and forensic examination conclusion in the study population $(\mathrm{n}=828)$.

\begin{tabular}{|c|c|c|}
\hline Variables & n & $\%$ \\
\hline \multicolumn{3}{|l|}{ Demographic data } \\
\hline \multicolumn{3}{|l|}{ Age group (years) } \\
\hline$<10$ years & 611 & 73.8 \\
\hline Pre-adolescent (10-11 years) & 217 & 26.2 \\
\hline \multicolumn{3}{|l|}{ Sex of the child } \\
\hline Male & 197 & 23.8 \\
\hline Female & 631 & 76.2 \\
\hline \multicolumn{3}{|l|}{ Place of birth } \\
\hline Salvador & 602 & 72.7 \\
\hline Another town/city & 219 & 26.4 \\
\hline Data missing & 7 & 0.8 \\
\hline \multicolumn{3}{|l|}{ Place of residence } \\
\hline Salvador & 632 & 76.3 \\
\hline Another municipality within greater Salvador & 187 & 22.6 \\
\hline Data missing & 9 & 1.1 \\
\hline \multicolumn{3}{|l|}{ Historical data } \\
\hline \multicolumn{3}{|l|}{ Source of the report of sexual abuse } \\
\hline Abuse reported by the child during the interview & 557 & 67.3 \\
\hline A family member reported the abuse as told by the child & 230 & 27.8 \\
\hline The sexual abuse was witnessed by someone & 41 & 4.9 \\
\hline \multicolumn{3}{|l|}{ Type of sexual abuse reported } \\
\hline Included digital or penile penetration (anal or genital) & 298 & 36.0 \\
\hline No penetration & 349 & 42.1 \\
\hline Data missing & 181 & 21.9 \\
\hline \multicolumn{3}{|l|}{ Interval between the reported abuse and the forensic examination } \\
\hline$\leq 24$ hours & 150 & 18.1 \\
\hline$>24$ to 72 hours & 126 & 15.2 \\
\hline From 3 to 7 days & 99 & 12.0 \\
\hline From 8 to 15 days & 43 & 5.2 \\
\hline$>15$ days & 178 & 21.5 \\
\hline Data missing & 232 & 28.0 \\
\hline \multicolumn{3}{|l|}{ Sex of the perpetrator } \\
\hline Male & 798 & 96.4 \\
\hline Female & 19 & 2.3 \\
\hline Data missing & 11 & 1.3 \\
\hline \multicolumn{3}{|l|}{ Family relationship between the child and the perpetrator } \\
\hline Yes & 398 & 48.1 \\
\hline No & 370 & 44.7 \\
\hline Data missing & 60 & 7.2 \\
\hline \multicolumn{3}{|l|}{ Conclusion of the forensic examination } \\
\hline \multicolumn{3}{|l|}{ The forensic physician was able to confirm sexual abuse } \\
\hline Yes & 86 & 10.4 \\
\hline No & 742 & 89.6 \\
\hline
\end{tabular}

alence ratios (PR) and 95\% confidence intervals of the variables included in the model as a function of whether sexual abuse was confirmed. Table 3 also shows the variables that remained in the final model with a significance level $<5 \%$ in the Wald test using the Poisson regression method with a robust error variance. The goodnessof-fit test confirmed the adequacy of the model 
Table 2. Distribution of the independent variables as a function of whether the sexual abuse was confirmed by the forensic physician based on material evidence $(n=828)$.

\begin{tabular}{|c|c|c|c|c|c|}
\hline Variable & $\begin{array}{l}\text { Unconfirmed } \\
\qquad(\mathrm{n}=742)\end{array}$ & $\%$ & $\begin{array}{c}\text { Confirmed } \\
(\mathrm{n}=86)\end{array}$ & $\%$ & p-value ${ }^{*}$ \\
\hline Age group & $(\mathrm{n}=742)$ & & $(\mathrm{n}=86)$ & & $<0.001$ \\
\hline$<10$ years & 564 & 92.3 & 47 & 7.7 & \\
\hline Pre-adolescent (10-11 years) & 178 & 82.0 & 39 & 18.0 & \\
\hline Sex of the child & $(\mathrm{n}=742)$ & & $(\mathrm{n}=86)$ & & 0.354 \\
\hline Female & 562 & 89.1 & 69 & 10.9 & \\
\hline Male & 180 & 91.4 & 17 & 8.6 & \\
\hline Place of birth & $(\mathrm{n}=735)$ & & $(\mathrm{n}=86)$ & & 0.038 \\
\hline Salvador & 547 & 90.9 & 55 & 9.1 & \\
\hline Another city & 188 & 85.8 & 31 & 14.2 & \\
\hline Place of residence & $(\mathrm{n}=733)$ & & $(\mathrm{n}=86)$ & & 0.361 \\
\hline Salvador & 569 & 90.0 & 63 & 10 & \\
\hline Another city & 164 & 87.7 & 23 & 12.3 & \\
\hline Source of the report of abuse & $(\mathrm{n}=742)$ & & $(\mathrm{n}=86)$ & & 0.048 \\
\hline $\begin{array}{l}\text { Report of sexual abuse made by the child during the } \\
\text { interview }\end{array}$ & 489 & 87.8 & 68 & 12.2 & \\
\hline $\begin{array}{l}\text { Report of sexual abuse made by the person accompanying } \\
\text { the child }\end{array}$ & 215 & 93.5 & 15 & 6.5 & \\
\hline Someone witnessed the sexual abuse & 38 & 92.7 & 3 & 7.3 & \\
\hline Sex of the perpetrator & $(\mathrm{n}=821)$ & & $(\mathrm{n}=86)$ & & $0.248^{* *}$ \\
\hline Female & 19 & 100 & 0 & 0.0 & \\
\hline Male & 712 & 89.2 & 86 & 10.8 & \\
\hline Family relationship between the child and the perpetrator & $(\mathrm{n}=689)$ & & $(\mathrm{n}=79)$ & & 0.034 \\
\hline Yes & 366 & 92.0 & 32 & 8.0 & \\
\hline No & 323 & 87.3 & 47 & 12.7 & \\
\hline Form of sexual abuse reported & $(\mathrm{n}=578)$ & & $(\mathrm{n}=69)$ & & $<0.001$ \\
\hline Included digital or penile penetration (anal or genital) & 241 & 80.9 & 57 & 19.1 & \\
\hline No penetration & 337 & 96.6 & 12 & 3.4 & \\
\hline Time between the sexual abuse and the forensic examination & $(\mathrm{n}=522)$ & & $(\mathrm{n}=74)$ & & 0.002 \\
\hline$\leq 24$ hours & 120 & 80.0 & 30 & 20.0 & \\
\hline$>24-72$ hours & 116 & 92.1 & 10 & 7.9 & \\
\hline Between 3 and 7 days & 95 & 96.0 & 4 & 4.0 & \\
\hline Between 8 and 15 days & 38 & 88.4 & 5 & 11.6 & \\
\hline$>15$ days & 153 & 86.0 & 25 & 14.0 & \\
\hline
\end{tabular}

* Chi-square test; ** Fisher's exact test.

used, with $p>0.05$ (0.937 for the goodness-offit; Pearson's chi-square test), while the omnibus test confirmed the statistical significance of the model $(\mathrm{p}<0.001)$.

The adjusted analysis showed that the variables place of birth, source of the report of abuse, family relationship between the child and the perpetrator, and the time between the reported abuse and the forensic examination were not in- dependently associated with finding evidence of sexual abuse in the forensic examination. In the final model, a report of penetration was associated with a five-fold greater likelihood of sexual abuse confirmation. When the victim was 10 to 11 years of age (pre-adolescent) rather than younger, there was a two-fold greater likelihood of the sexual abuse being confirmed in the forensic examination. 


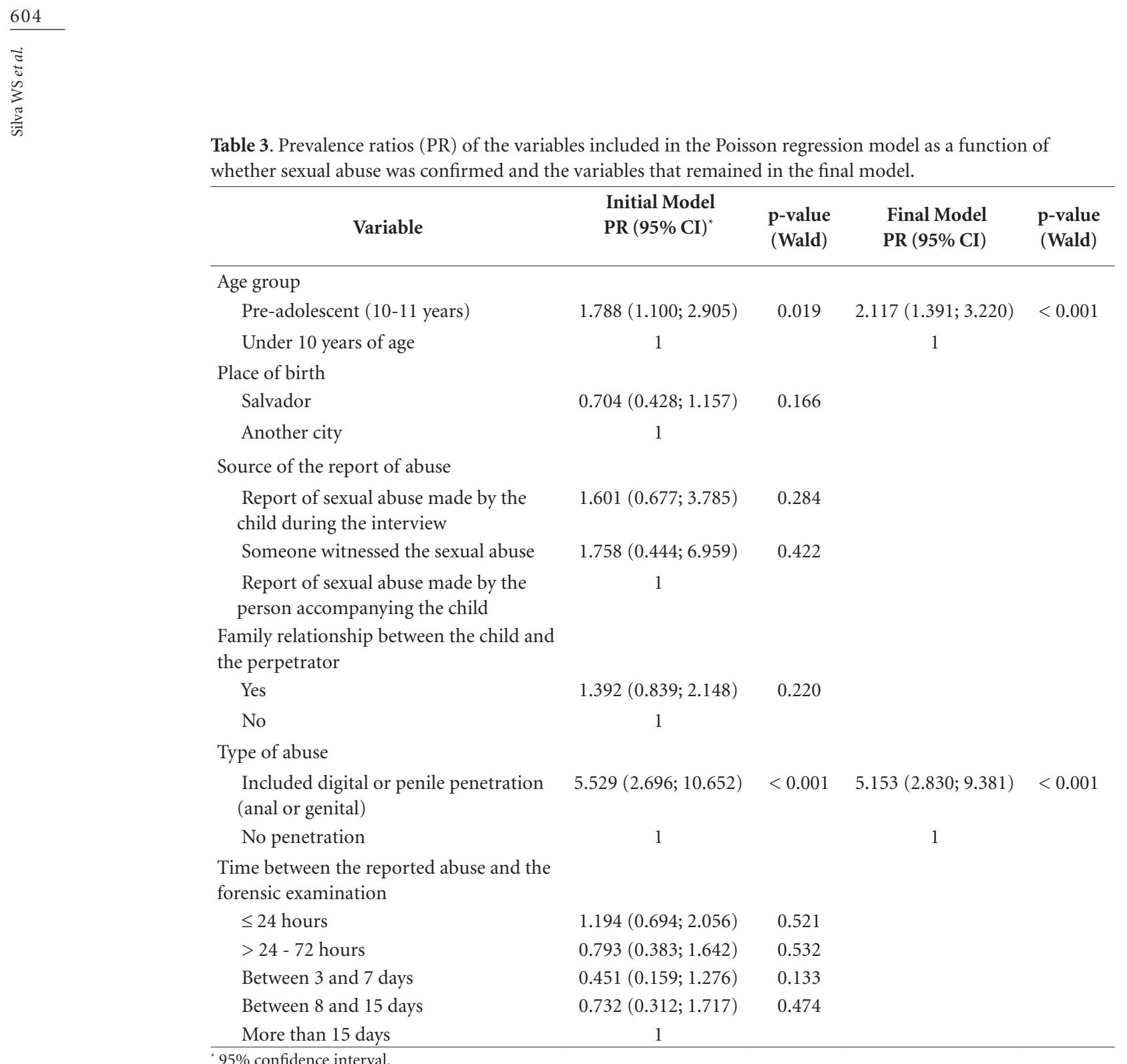

\section{Discussion}

The finding that the forensic physician was able to confirm sexual abuse in $10.4 \%$ of cases based on material evidence is similar to the results found in a study conducted by Anderst et al..$^{18}$ in a children's advocacy centre. Nevertheless, in that study, the authors only included female victims of sexual abuse who had reported anal or vaginal penetration, whereas the present study included both boys and girls, with $36 \%$ of the victims having reported penetration. In a study conducted by Modelli et al. ${ }^{13}$ with children receiving a forensic examination, the forensic physician was able to confirm $3.5 \%$ of the cases of sexual abuse in girls and $9.6 \%$ of the cases in boys. Heger et al. ${ }^{19}$ found that $4 \%$ of the cases of sexual abuse were confirmed in a population of 2,300 children referred to referral centres for sexual abuse. In another study of children investigated for sexual abuse in Nina Rodrigues Institute of Forensic Medicine, from 2005 to $2010,8.4 \%$ of the cases were confirmed by the coroner for material evidence $^{14}$. However, this series also included cases in which investigation was triggered by an abnormal anogenital finding even in the absence of a sexual abuse allegation. The differences in the selection criteria used in the various studies mentioned above may have led to these different results.

In the adjusted analysis, no association was found between finding evidence of sexual abuse 
and the time interval between the reported abuse and the forensic examination. This finding should be interpreted with caution since this information was missing in $28 \%$ of the cases in this study sample. In the study conducted by Anderst et al. ${ }^{18}$, no association was found between definitive findings of penetration and the time interval between the abuse and the examination. However, this study only included girls with time intervals longer than 72 hours between the reported abuse and examination. Furthermore, in the present study, no association was found between sexual abuse confirmation and place of birth, source of the report of abuse, or the presence of a family relationship between the victim and the perpetrator.

In the Poisson regression analysis, the only factors that remained significantly associated with sexual abuse confirmation after the progressive removal of the nonsignificant variables according to the Wald test were those related to penetration and age group. The presence of a report of penetration in the case history was associated with a five-fold greater likelihood of confirmation of sexual abuse in the present study. It was not possible to compare this finding with the results from the study conducted by Anderst et al. ${ }^{18}$, in which the proportion of confirmed cases was similar to our study, because the population in that study consisted exclusively of cases in which penetration had been reported. In a study that included children, adolescents and adults, Sudupe Moreno ${ }^{10}$ found a three-fold greater likelihood of encountering forensic evidence of physical injury in cases of sexual assault with penetration.

Confirmation of sexual abuse was twice as likely in cases involving pre-adolescent children than children less than 10 years of age, even after adjustment for reported penetration. This finding appears to support the hypothesis published in the literature ${ }^{12}$ that smaller children may report friction or attempted penetration beyond the labia majora up to the vulvar vestibule as vaginal penetration because they lack any reference on which to base their experiences. Therefore, reports of penetration in older children may perhaps be more closely associated with actual penetration compared to reports from younger children.

When interpreting the present study's results, the methodologies used and their limitations need to be taken into consideration. This study followed a retrospective design and the aspects evaluated were limited to the information con- tained in the forensic reports. A convenience sample was used, and a selection bias could result in differences in relation to a population-based sample. It is estimated that only $10 \%$ of cases of child sexual abuse reach the ears of the child protection authorities ${ }^{20}$. It is probable that there is a selection of children in case studies in which the evidence of abuse is greater. The fact that the forensic physician interpreting the findings of the physical examination is the same physician who records the child's report may introduce a bias, since clinical history may influence his/her interpretation of the findings encountered. Despite these limitations, the fact that cases were included consecutively over a two-year period, and that the study was conducted in an institute that receives all cases of children undergoing forensic examination for suspected sexual abuse in this geographic area gives strength to the study.

In conclusion, in children reporting sexual abuse, the rate of confirmation of the abuse based on material evidence during forensic medical examination is low. For those reporting penetration and in the case of pre-adolescents, the likelihood of obtaining confirmation is greater. These data should be taken into consideration when drawing up guidelines for the multidisciplinary evaluation of children suspected of being victims of sexual abuse and in deciding whether to refer the child for forensic medical examination.

\section{Collaborations}

WS Silva worked in the design, data collection and analysis, and article writing, under the supervision of UO Barroso-Júnior. FM Ribeiro, GK Guimarães, MS Santos, and VPS Almeida worked on the collection and analysis of data.

\section{Acknowledgements}

This article is part of Welington dos Santos Silva PHD Thesis of Bahian School of Medicine and Public Health Post-Graduate Course. We are grateful to the teachers who collaborated with criticisms and suggestions to this research. 


\section{References}

1. Kempe CH. Sexual abuse, another hidden pediatric problem: The 1977 C. Anderson Aldrich lecture. Pediatrics $1978 ; 62(3): 382-389$.

2. Johnson CF. Child sexual abuse. Lancet 2004; 364(9432):462-470.

3. Pereda N, Guilera G, Forns M, Gómez-Benito J. The prevalence of child sexual abuse in community and student samples: a meta-analysis. Clin Psychol Rev 2009; 29(4):328-338.

4. Stoltenborgh M, van Ijzendoorn MH, Euser EM, Bakermans-Kranenburg MJ. A global perspective on child sexual abuse: meta-analysis of prevalence around the world. Child Maltreat 2011; 16(2):79-101.

5. World Health Organization (WHO). Guidelines for medico-legal care for victims of sexual violence. [cited 2015 Aug 1]. Available from: http://apps.who.int/iris/ bitstream/10665/42788/1/924154628X.pdf

6. Brasil. Decreto $\mathrm{n}^{\circ} 7.958$, de 13 de março de 2013. Estabelece diretrizes para o atendimento às vítimas de violência sexual pelos profissionais de segurança pública e da rede de atendimento do Sistema Único de Saúde. Diário Oficial da União 2015; 14 mar.

7. Brasil. Lei $\mathrm{n}^{\circ} 12.845$, de $1^{\circ}$ de agosto de 2013. Dispõe sobre o atendimento obrigatório e integral de pessoas em situação de violência sexual. Diário Oficial da União 2015; 2 ago.

8. Brasil. Portaria $\mathrm{n}^{\circ} 485$, de 1 de abril de 2014. Redefine o funcionamento do Serviço de Atenção às Pessoas em Situação de Violência Sexual no âmbito do Sistema Único de Saúde (SUS). Diário Oficial da União 2015; 2 abr.

9. Brasil. Portaria Interministeria $\mathrm{n}^{\circ} 288$, de 25 de março de 2015. Estabelece orientações para a organização e integração do atendimento às vítimas de violência sexual pelos profissionais de segurança pública e pelos profissionais de saúde do Sistema Único de Saúde (SUS). Diário Oficial da União 2015; 26 mar.

10. Sudupe Moreno A. Age differences among victims of sexual assault: A comparison between children, adolescents and adults. J Forensic Leg Med 2013; 20(5):465470 .
11. Adams JA, Kellogg ND, Farst KJ, Harper NS, Palusci VJ, Frasier LD, Levitt CJ, Shapiro RA, Moles RL, Starling SP. Updated Guidelines for the Medical Assessment and Care of Children Who May Have Been Sexually Abused. J Pediatr Adolesc Gynecol 2016; 29(2):81-87.

12. Adams JA. Medical evaluation of suspected child sexual abuse. J Pediatr Adolesc Gynecol 2004; 17(3):191-197.

13. Modelli MES, Galvão MF, Pratesi R. Child sexual abuse. Forensic Sci Int 2012; 217:1-4.

14. Silva WS, Barroso-Júnior UO. Características de los menores de 12 años con examen médico forense por sospecha de abuso sexual en Salvador, Brasil. Rev Española Med Leg 2015; 42(2):55-61.

15. Instituto Brasiliero de Geografia e Estatística (IBGE). Census 1010. [cited 2015 Jan 19]. Available from: http:// www.censo2010.ibge.gov.br/

16. Barros AJ, Hirakata VN. Alternatives for logistic regression in cross-sectional studies: an empirical comparison of models that directly estimate the prevalence ratio. BMC Med Res Methodol 2003; 3:21.

17. SPSS Inc. SPSS for Windows, version 14.0. Chicago: SPSS Inc; 2005.

18. Anderst J, Kellogg N, Jung I. Reports of repetitive penile-genital penetration often have no definitive evidence of penetration. Pediatrics 2009; 124:e403-409.

19. Heger A, Ticson L, Velasquez O, Bernier R. Children referred for possible sexual abuse: medical findings in 2384 children. Child Abuse Negl 2002; 26(6-7):645-659.

20. MacMillan HL, Jamieson E, Walsh CA. Reported contact with child protection services among those reporting child physical and sexual abuse: results from a community survey. Child Abuse Negl 2003; 27(12):1397408.

Artigo apresentado em 03/12/2015

Aprovado em 10/05/2016

Versão final apresentada em 12/05/2016 